\title{
Öğretmenlerin Kitap Önerisinde Kullandıkları Ölçütlerin Çocuk Edebiyatının Temel İlkelerine Göre İncelenmesi
}

\section{Examining the Criteria Used by Teachers in Suggesting Books Based on the Main Principles of Children's Literature}

\author{
Görkem Arslan *(i) ve Tolga Kargın*
}

$\ddot{O}_{z}$

Amaç: Bu çalışma, ilkokul, ortaokul ve ortaöğretim kademelerinde görev yapmakta olan Türkçe, Türk dili ve edebiyatı ile sinıf ögrretmenlerinin ögrencilere kitap önerirken göz önünde bulundurdukları ölçütleri ortaya koymak ve çocuk edebiyatı eserlerinde bulunması gereken temel ölçütler bağlamında değerlendirmek amacıyla gerçekleştirilmiştir. Yöntem: Temel nitel araştırma modelinde tasarlanmış olan bu çalışmada on sorudan oluşan bir yarı yapılandırılmış görüşme formu veri toplama aracı olarak kullanılmıştır. Araştırmacı tarafindan hazırlanıp beş alan uzmanı tarafindan gözden geçirilerek düzenlenmiş on adet açık uçlu sorudan oluşan form; beş sınıf ögretmeni, beş Türkçe öğretmeni ile beş Türk dili ve edebiyatı öğretmenine çevrimiçi görüşme yoluyla sunularak veriler elde edilmiştir. Elde edilen veriler betimsel analize tabi tutularak bulgulara ulaşılmıştır. Bulgular: Öğretmenlerin kitap önerisinde bulunurken göz önünde bulundurdukları ölçütlere bakıldiğında görü̈sme yapılan 15 ögretmenin tamamının eğitsel öğeleri, 12 ögretmenin dil ve anlatım unsurlarını, 11 ögretmenin içerik unsurlarını, 7 ögretmenin de biçim unsurlarını dikkate aldıkları bulgusuna ulaşılmıştır. Ayrıca 15 öğretmenin tamamı kitapların çocuğa görelik ilkesine uygun olup olmamasını dikkate alırken yalnızca 6 ögretmen kitapların çocuk gerçekliği ilkesine uygunluğunu dikkate almıştır. Sonuç: Çalışmanın sonucunda ögrretmenlerin çocuk edebiyatı ürünlerinde en çok çocuğa görelik ilkesine önem verdikleri, çocuk edebiyatı ürünlerinin eğitsel yönünün tüm branşlar tarafindan en çok önemsenen özellik olduğu, ögrencilerin yaş ve gelişim seviyelerine bağlı olarak öğretmenlerin kitapların içerik yönüyle ilgili beklentilerinin yerini dil ve anlatım unsurlarının aldı̆̆g, öğretmenlerin ögrencilerine en çok önerdikleri türler olarak öykü türünün öne çıktığı anlaşılmıştır. Özgünlük: Sınıf, Türkçe ve Türk dili ve edebiyatı öğretmenlerinin öğrencileri için kitap seçmede göz önünde

\footnotetext{
${ }^{*}$ Milli Eğitim Bakanlığı, Burhaniye İlçe Milli Eğitim Müdürlüğü, Balıkesir, Türkiye, E-posta: gorkem.yasar1@gmail.com Ministry of National Education, Burhaniye Directorate of National Education, Ballkesir, Turkey, E-mail: gorkem.yasar1@gmail.com,

** Uşak Üniversitesi, Sınıf Eğitimi Anabilim Dalı, Uşak, Türkiye. E-posta: tolga.kargin@usak.edu.tr

Usak University, Department of Elementary Education, Usak, Turkey: E-mail: tolga.kargin@usak.edu.tr
}

Geliş Tarihi-Received: 06.09.2021

Kabul Tarihi - Accepted: 12.12.2021

Yayımlanma Tarihi - Published: 30.12.2021 
bulundurdukları ölçütleri ortaya koyan bu çalışma, bu ölçütleri çocuk edebiyatının temel ölçütleri çerçevesinde değerlendirmesi bağlamında özgün bir çalışmadır.

Anahtar Sözcükler: Kitap önerisi, çocuk, çocuk edebiyatı, ögretmen, okuma.

\begin{abstract}
Purpose: This study was carried out to reveal the criteria that Turkish, Turkish language and literature and class teachers, who are working at primary and secondary education levels, consider when recommending books to students, and to evaluate them in the context of the main principles that should be found in children's literature works. Method: In this study, which was designed in the basic qualitative research model, a semi-structured interview form consisting of ten questions was used as a data collection tool. The form consisting of ten open-ended questions prepared by the researchers and reviewed by five field experts. Data were obtained by interviewing five class teachers, five Turkish teachers, and five Turkish language and literature teachers through online meetings. The obtained data were subjected to descriptive analysis and the findings were reached. Findings: Looking at the criteria that the teachers considered while suggesting a book, it was found that all the 15 teachers interviewed took into account the educational elements, 12 teachers considered the language and expression elements, 11 teachers considered the content elements, and 7 teachers considered the form elements. In addition, while all 15 teachers took into account whether the books were suitable for the principle of being suitable for the child, only 6 teachers considered the compliance of the books with the principle of child reality. Implications: As a result of the study, it was concluded that the principle of being suitable for children in children's literature products is given the most importance by teachers, the educational aspect of children's literature products is considered the most important feature by all branches, the language and expression elements have replaced the teachers' expectations about the content of the books, depending on the age and development levels of the students, and it was understood that the genre of story is the most recommended genre by the teachers to their students. Originality: This study, which reveals the criteria that class, Turkish and Turkish language and literature teachers consider in choosing books for their students, is an original study in the context of evaluating these criteria within the framework of the main principles of children's literature.
\end{abstract}

Keywords: Book recommendation, child, children's literature, teacher, reading.

\title{
Giriş
}

Okuma becerisi; diğer dil becerileri ile birlikte düşüncenin ve düşünmenin gelişimi açısından mihenk taşı işlevi gören yaşantıların elde edilmesinde başat rolü oynar. Yaşamın her alanında olduğu gibi akademik yaşamda da okuma ile elde edilecek deneyimlerin rolü, temel eğitim ve ortaöğretim çağındaki çocuklarda daha da önemli bir yere sahiptir. Bu bakımdan, okuma becerisinin geliştirilmesi ve bu becerinin bir alışkanlığa dönüştürülerek kalıcılaştırılması; okuma-yazmanın öğrenildiği dönemden itibaren her sınıf düzeyinde dikkatle üzerinde durulması gereken bir kazanımdır. 
Daha anne karnında iken dinlemenin sistematik ve amaca dönük olarak geliştirilmesi amacıyla çocuk kitapları ve çocuklar için hazırlanmış diğer yayınlar işe koşulduğunda insan yavrusunun zihinsel gelişimi için çok önemli bir adım atılmış olacaktır. Okul öncesi çağda gerek aile gerekse öğretmenler tarafindan kararlı biçimde sürdürülen bu okuma tanışıklı̆ı, temel öğretime başlayan bir öğrenci için güçlü bir düşünce ve hayal dünyası sağlar. "Okuma becerisinin gelişerek devam etmesi, zorunlu eğitim içinde atılan temellere bağlıdır. Bu dönemdeki temelin kökleri ne kadar sağlam olursa ilerdeki dönemlerde de gelişme ve alışkanlık o kadar başarılı olur" (Özbay, 2009, s. 42). Temel ve ortaöğretimde formal ve informal eğitim ile okul içi ve dışında desteklenerek biçimlendirilen okuma becerisi; çocuk edebiyatının temel ölçütlerine uygun, yetkin kitaplar ile bir alıskanlığa dönüştürüldüğünde öğrenci önemli bir avantaj elde edecektir.

Çocuk için uygun kitapların seçiminde hem ailenin hem de öğretmenlerin rolü eşit olmakla birlikte ülkemizdeki sosyoekonomik ve eğitsel farklıllklar dolayısıyla öğretmenlere düşen görev oldukça büyüktür. Okuma becerisi ve alışkanlığı ilköğretim çağında kazanılan bir beceri (Batur ve Alevli, 2014) olduğu için -tüm branş öğretmenlerine görev düşmekle birlikteöğretim programlarındaki kazanım ve hedefler de göz önünde bulundurulduğunda sınıf öğretmenleri ve Türkçe öğretmenlerinin rolü ve etkisi önemlidir. Çocuğun hayal ve düşünce evreninin geliştirilmesine hizmet eden, derinlikli kitapların seçimi konusunda bilgisi ve deneyimi olan öğretmenler, doğru kitap seçimleriyle öğrenciye yeni ufuklar açar. Bir heykelin güzelliği nasıl heykeltıraşın başarısıysa; kültür seviyesi, bilgi seviyesi ve etkileme yeteneğiyle öğrencilerin kişilik gelişiminde aktif rol oynayan öğretmenlerin, öğrencilerinin okuma alışkanlığı kazanmasında büyük etkisi vardır (Gürcan, 1999). Bu sebeple Türkçe öğretmenlerinin (Kaya, 2007), sınıf öğretmenlerinin ve Türk dili ve edebiyatı öğretmenlerinin çocuk edebiyatı ilkelerini bilmeleri ve kitap seçiminde göz önünde bulundurmaları gerekmektedir.

Çocukların hem aile çevrelerinin hem de okul çevrelerinin kitap okumaya bakışları ve kitap okuma deneyimleri çocukların okuma alışkanlığı edinmelerinde önemli bir etkiye sahiptir (Ateş, Çetinkaya ve Yıldırım, 2012). Öğrenci, okulda öğretmenin rehberliğinde özerk olarak sürdüreceği başarılı bir okuma deneyimi elde ettiğinde yavaş yavaş kendi bağımsız okuma sürecini oluşturup yönetebilecek duruma gelecektir. İlkokul ve ortaokulda temelleri atılan okuma alışkanlı̆̆ dokunuşlarıyla pekişecek ve ivme kazanacaktır.

\section{Çocuk Edebiyatı Ürünlerinde Temel Ölçütler}

Çocuk edebiyatı esasında çocuğu ve çocukluğu kaynak edinen bir geçiş dönemi edebiyatıdır. İçeriğin çocuğa görelik ve çocuk gerçekliği ilkelerine uygun olarak hazırlanıp mümkün olduğunca sade bir biçimde aktarıldığı, çocuğun okuma alışkanlığı kazanmasına ve estetik duygularının gelişmesine katkı sağlayan edebi eserlerden oluşmaktadır (Şirin, 2007). Çocukların ilgi, eğilim ve beklentilerini göz önünde bulundurarak gelişimsel özelliklerine uygun kitaplar seçmek isteyen bir öğretmenin bunu yaparken kılavuzu çocuk edebiyatının temel ölçütleri olmalıdır. Çocuk edebiyatı ürünlerinde bulunması gereken temel ölçütler ana hatlarıyla birçok araştırmacı tarafından benzer şekilde ele alınsa da farklı araştırmacılar bu 
temel ölçütleri farklı şekillerde gruplamışlardır. Karatay (2011b) çocuk edebiyatı ürünlerinde bulunması gereken özellikleri biçimsel özellikler ve içerik özellikleri olmak üzere iki başlık altında ele almıştır. Biçimsel özellikler görseller, sayfa tasarımı, kapak tasarımı, boyut ve cilt yapısı ile ilgili iken içerik özellikleri edebî unsurlar, konu seçimi, karakterler, kurgu, üslup ve ileti ile ilgilidir. Karatay (2011b), söz varlığı unsurları ve söz sanatlarını da dil ve anlatım başlığı altında ele almıştır. Türkben ve Avan (2020) ise çocuk edebiyatı ürünlerinin biçimsel ve içerik özelliklerinin yanı sıra eğitsel özellikleri bakımından da değerlendirilmesini önermişlerdir.

$\mathrm{Bu}$ çalışmada ise çocuk edebiyatı ürünlerinin temel ölçütleri dört ana başlık altında toplanmıştır: Biçimsel özellikler, içerik özellikleri, dil ve anlatım özellikleri ve eğitsel ögeler. Biçimsel özellikler, birçok araştırmada olduğu gibi kitabın boyutu, kapak tasarımı, ciltlenmesi, sayfa düzeni, kullanılan harflerin boyutu ve yazım şekli ve kitapta kullanılan görseller ile ilgili iken, içerik özellikleri konu, izlek, ileti, plan ve karakterler ile sınırlı tutulmuştur. Bir kitabın çocuğa göre olup olmadığını değerlendirmede ön plana çıkan dil ve anlatım özelliği ile kitaptaki eğitsel ögeler ise içerik özellikleri başlığının altından çıkarılarak ayrı başlıklar olarak ele alınmıştır.

\section{Çocuk kitaplarında bulunması gereken biçimsel özellikler}

Şüphesiz, çocuk kitaplarının görsel ve fiziksel açıdan çocukların yaş ve gelişim düzeylerine uygun şekilde hazırlanması gerekir. Kitaplardaki resimler, metnin iletisini destekler nitelikte olmalı, çocukların algı düzeyine uygun ve görsel algılarını geliştirici özellikler taşımalıdır (Sever, 2008). Görsellerin dağılımı, kitabın boyutu ve kullanılan malzemeler ile sayfa düzeni, harf ve karakterlerin puntolarının yaş düzeyine uygunluğundan sayfa ve satır boşluklarına, hatta satır başlarının hizasına kadar; okumayı zorlaştırıcı her türlü etkenden arındırılmış bir görünüm ve tasarım; çocuk kitaplarından beklenen biçimsel özellikler olarak ifade edilebilir.

Çocuk kitaplarının boyut ve ağırlıkları ile cilt yapıları çocukların yaş düzeyine uygun olmalıdır. Hem estetik açıdan ilgi çekici hem de içeriğe ilişkin fikir verici nitelikte olması beklenen kapak tasarımının yanında kitabın cildinin sağlam olması (Sever, 1995), malzeme seçimi bakımından gelişimsel düzeye uygun ve kullanışlı olması da bir diğer biçimsel özellik olarak değerlendirilebilir.

Okunurluğun ve dayanıklılığın sağlanması açısından üçüncü hamur tipi kâğıt kullanımı uygun değildir (Çolaklar, 2019). Sayfa tasarımı bakımından ise resimler ile metinlerin uyumlu bir şekilde yerleştirilmiş olması, sayfaların hem estetik hem de biçimsel açıdan oransal uyum kurallarına uygun biçimde tasarlanması gerekmektedir (Oral, 1994).

\section{Çocuk kitaplarında bulunması gereken içerik özellikleri}

Çocuk kitaplarında içeriğe ilişkin olarak çocuğun dil ve düşünce evrenine katkıda bulunma gayesi, çocukta okuma ilgi ve alışkanlığ oluşturup geliştirmeye yarayacak ilgi çekicilik özelliği ile öğreticilik unsurları önem arz etmektedir. Çocuk edebiyatı ürünleri gerek kullanılan dil gerekse görsellerle çocuklara yeni yaşantılar sunmalı ve bu yaşantılardan çıkarımda bulunma işi çocuklara bırakılmalıdır (Sever, 2008). Çocuk kitaplarının sistematik bir biçimde örülmüş örtük değerler ăğ biçiminde kurgulanması bu açıdan önemlidir. Çocuk kitapları belli bir ideolojinin çocuğa empoze edilmesi amacıyla kullanılacak birer araç olarak 
görülmemelidir. Çocuklara evrensel ve insanî değerleri kazandırıcı; bireysellikten toplumsallığa, toplumsallıktan evrenselliğe ulaştırıcı nitelikte tema ve konuların etkili, estetik bir dil ve anlatımla ele alınması çocukta aynı zamanda okuma sevgisi de oluşturmada önemli bir etkendir.

Çocuk edebiyatı ürünleri toplumsal iletişim ve demokrasi kültürünün edinilmesi bakımından oldukça önemli araçlardır. Çocuk, çocuk edebiyatı yapıtları aracıllğıyla küçük yaşlardan itibaren demokrasi kültürüne ilişkin kavramlarla karşılaştırılmalıdır (Gedikoğlu Özilhan, 2016). Yaşamdaki anlaşmazlıkların demokrasi kültürü ve iletişimle çözüleceğine ilişkin zihinsel kod, çocuk kitapları aracılığıyla çocuğa sezdirilmelidir.

"Çocuk edebiyatı yapıtlarında yazınsal bir kurguyla geliştirilen izlek, insana özgü duygu durumlarını çocuklarda yaşatabilmeli; çocuklar kaynağını sevgiden alan konularda duyarak, gülerek, düşünerek, hüzünlenerek dostluğun, barışın, çalışkanlığın, paylaşmanın yüceliğini sezebilmeli, güven duygularını geliştirebilmelidir" (Sever, 2013, s. 129). Çocuk edebiyatı ürünlerinde ele alınan izlek ve konular; çocuğun yaşamda karşılaşabileceği problem durumlarını insancıl yollarla ve kendisini, çevresini geliştirip koruyacak biçimde çözmesini sağlayacak becerileri kazandıracak biçimde kurgulanmalıdır.

Kahramanlar çocuğa rol model teşkil edebilecek, çocuğun gerçek yaşam problemleri ile baş etmesini sağlayacak özelliklerle yoğrulmalıdır. Çocukları günlük hayatta uyulması gereken toplumsal kurallar ya da bir davranışın olumlu veya olumsuz sonuçları hakkında sözlü olarak bilgilendirmekten ziyade çocuk edebiyatı eserlerinde öykü kahramanları aracılığı ile bilgilendirmek daha etkili olacaktır (Karatay, 2011a). Çocuğa verilmek istenen iletiler, kazandırılmak istenen beceri ve davranışlar karakterlerin davranış ve kişiliklerine işlenerek örtük biçimde verilmelidir.

Çocuk kitaplarında karakter özellikleri ve kurgudaki çatışmaların çocuğa uygunluğu, çocuğun zihinsel ve duygusal gelişimine katkısı bakımından önemlidir. Kurguda ele alınan çatışmalar, çocuğa verdiği mesajlarla çocuğun zihinsel ve duyuşsal gelişimini etkileyeceği gibi çocuğun kitaba ilgisini ayakta tutacak gerilimin de sağlayıcısı olması bakımından okuma ilgi ve alışkanlığının geliştirilmesinde etkilidir. Sever'e göre (2008) çatı̧̧alar kişiler arası çatışma, kişinin kendisiyle çatışması, kişinin doğayla çatı̧̧ması, kişinin toplumla çatışması biçiminde dört biçimde ele alınmaktadır. Çatı̧̧malar; kurgusal çocuk kitaplarında olayın başlatılıp geliştirilmesi ve sonuçlandırılmasının yanında yer, zaman gibi unsurların biçimlendirilmesinde de -çocuğa göre ve çocuk için- etkili bir anlatım aracı olarak kullanılmalıdır.

\section{Çocuk kitaplarında bulunması gereken temel eğitsel özellikler}

Çocuk edebiyatı ürünleri, edebiyat sanatının ve dilin imkânlarını çocuğun duygu ve düşünce dünyasının hizmetine sunmak amacıyla yazılmış olmalıdır. Bir çocuk kitabının çocuk edebiyatı eseri olarak kabul edilmesi için kitabın biçimsel ve içerik özelliklerinin birbirini tamamlaması ve çeşitli eğitsel ilkelerini de içermesi gerekmektedir (Sever, 2006). Arıkan ve İnce Samur'a (2020, s. 185) göre, çocuklara yönelik hazırlanan kitaplarda bulunması gereken temel eğitsel nitelikler şu şekilde sıralanabilir: Çocuk kitapları mantığa uygun ve çocukların değerler sistemi geliştirmesine imkân sunacak şekilde yazılmalıdır; çocuk kitapları erkek ve 
kadınlara atfedilen toplumsal cinsiyet yargılarından arındırılmış olmalıdır; çocuk kitaplarının kurgusu ve verdikleri mesajlar çocukların kişilik gelişimlerine katkı sağlar nitelikte olmalıdır; çocuk kitaplarında aktarılan olaylar baskıcı ve denetimci bir yaklaşım içermemelidir; çocuk kitapları yaşanan her şeyin alın yazısı olduğu ve değişemeyeceği görüşünü onaylamamalıdır; çocuk kitapları çocukların aktif ve girişimci bir kimlik geliştirmesini destekler nitelikte yazılmalıdır ve çocuk kitapları çocukların hayal gücünün gelişimine katkı sağlamalıdır.

Çocuk edebiyatı ürünlerinde çocukların zihinsel ve duygusal gelişimleri için gerekli olan bilgi ve deneyimlerin kazandırılması esas ise de iletilerin doğrudan verilmesi, eleştirel düşünmeye ve yeniden yapılandırmaya firsat vermeyecek şekilde bir dayatmaya gidilmesi ve iletinin kendisinin bir amaç olarak görülmesi sakıncalı olacaktır. Çocuk edebiyatı ürünlerinin amacı; eserin tüm unsurlarını bilinçli olarak düzenlenmiş bir uyum içerisinde kullanarak çocukların zihinsel ve duygusal gelişimlerini sağlamaktır. Dolayısıyla iletinin kendisini bir amaç olarak değil bir araç olarak görmek gerekmektedir. Bu durumda, Çer'in (2016c, s. 1402) de ifade ettiği gibi:

Sanatçı, çocukta estetik beğeni oluşturmalı; renk, çizgi ve sözcüklerle yarattığ1 imgelerle çocuğun düşsel ve düşünsel bir süreç içine girmesini sağlamalı; çocuğun kitapla karşılaştığı anda güzel ve doğru olana yönelik duygularını geliştirmeli; bilgi öğretmek yerine, duyumsatıcı biçimde çocuğa düş kurma ve düşünme sorumluluğu vermelidir.

\section{Çocuk kitaplarında bulunması gereken dil ve anlatım özellikleri}

Çocuk edebiyatı ürünlerini yetişkin edebiyatı ürünlerinden ayıran en önemli özelliklerden biri de dil ve anlatımdır (Akyüz, 2014). Çocuk kitapları çocuğa sosyal deneyimler kazandırmanın yanında geniş ve zengin bir dil dünyası sunar. Dil becerilerinin gelişimi için en güçlü seçenek, çocuklar için hazırlanmış edebi ürünlerdir. Çocuklar bu edebi ürünleri okuyarak yalnızca içinde yaşadıkları dünya hakkında bilgi edinmez aynı zamanda çeşitli konularda duyarlılık kazanırlar, hayal güçleri, iletişim güçleri ve yaratıcılık becerileri de gelişir (Demircan, 2006). Dilin anlatım olanaklarını en zengin şekilde sunmak, çocuk kitaplarından beklenen temel özelliklerden biridir. Duru, açık, akıcı bir anlatım ile çocuğun zihnine, kalbine ve hayallerine yakın bulabileceği bir okuma evreni sunabilmek; çocuk edebiyatı ürünlerinde bulunması gereken önemli bir özelliktir.

Dilidüzgün (2000, s. 257)'de "Çokanlamlılık, örtük ileti içerme, antiotoriter anlatım özellikleri, estetik bütünlük gibi temel yazınsal niteliklerin tümünü taşıması gerekir. Bunlara ek olarak yazınsal niteliği olan çocuk kitapları çocuk gerçekliğini ya da çocuğa görelik ilkesini görmezden gelemez" biçiminde yer bulan dil ve anlatıma ilişkin beklentiler; çocuğun dil ve düşünce evrenine edebiyatın gücünden yararlanarak estetik biçimde katkıda bulunabilme gayesi biçiminde özetlenebilir. Çocuklara aktarılacak olan duygu ve düşünceler, çocukların seviyesine uygun bir dil ile aktarılmalı, doğal bir anlatım kullanılarak Türkçe'nin güzelliği ve kuralları da çocuklara hissettirilmelidir (Sever, 2000).

Çocuk gerçekliği ve çocuğa görelik

Çocuk edebiyatında çocuğa görelik ve çocuk gerçekliği kavramları ön planda olan kavramlardır. Bu kavramlar, çocuklar için yazılan edebi eserlerin eğitsel, görsel ve estetik 
olarak sahip olması gereken ilkeleri ifade etmektedir (Şirin, 2016). Bu durumda çocuk edebiyatının en önemli özelliği, çocuğu ve çocukluğu anlayarak eserlerde kaynak olarak alan ve bu üç kavrama uygun olarak yazılan edebi eserleri içermesidir (Şirin, 2016). Çocuğun hayal, fikir ve dil evrenine uygun; aynı zamanda çocuğun erişi düzeyini artıracak kitaplar ile yola çıkmak gerekir. Çocuğa görelik olarak adlandırılabilecek olan bu özellik, çocuk kitaplarında aranan en temel özelliktir. Çocuk kitapları, çocuğun hayatını, dünyayı algılama şeklini, dil yeterliklerini, ilgi ve ihtiyaçlarını yansıtan gerçekliği ile yazınsal ölçütler ve sanatçı duyarlığını öncelediği oranda çocuğa göre olur (Çer, 2016a; 2016b; 2016c).

Çocuk gerçekliği ilkesi; kurgusal çocuk kitaplarında dahi, çocuğun gerçek yaşamına aktarabileceği, sosyal yaşam becerilerini çocuğa dikte etmeden kazandırabilen bir niteliği zorunlu kılar. Kitapta kendi hayatından bir şeyler gören çocuk, kendisini karakterle özdeşleştirebilir ve bu şekilde kitapta kendi hayatının temsil edildiğini görür ve kendini yalnız hissetmez. (Lifshitz, 2016). Çocuğun gerçek yaşamına aktaramayacă̆ı, yaşamdan tamamıyla kopuk ve sosyal ilişkilerde kullanılabilecek becerilerden uzak bir yapı; çocuk kitabından beklenen faydayı sağlamayacaktır.

Çocuk edebiyatı ürünleri, biçimsel özellikleri (boyut, kâğıt, kapak ve cilt, sayfa düzeni, resimler ve harf/punto), içerik özellikleri (izlek, konu, karakterler, çevre), dil ve anlatım özellikleri ve içerdiği eğitsel ögeler bakımından çocuğa görelik ve çocuk gerçekliği ilkelerine göre hazırlanmış olmalıdır (Sever, 2013). Öğrencilerine kitap önerisinde bulunan öğretmenlerin de bu süreçte çocuğa görelik ve çocuk gerçekliği ilkelerini dikkate almaları önem arz etmektedir.

\section{Amaç ve Önem}

$\mathrm{Bu}$ çalışmanın amacı; öğretmenlerin kitap önerisinde bulunurken göz önünde bulundurdukları ölçütleri ortaya çıkarmak ve bu ölçütleri çocuk edebiyatının temel ölçütleri bağlamında incelemektir.

Sınıf ve Türkçe öğretmenlerine anket yoluyla ulaşarak gerçekleştirdiği araştırmada Yazıcı Okuyan (2009), okullarda gerçekleştirilen okuma saatleri içerisinde okunacak kitapların seçiminde öğretmenlerin kitapların iç yapısına ve içerdiği eğitsel özelliklere daha fazla önem verdikleri sonucuna ulaşmıştır. Maltepe (2009), Türkçe öğretmeni adaylarıyla gerçekleştirdiği araşıımasında öğretmen adaylarının çocuk edebiyatı ölçütlerine yeterince hâkim olmadıkları sonucuna ulaşmıştır.

Öğrencilerin kendi yaşlarına/seviyelerine uygun, çocuk edebiyatı ölçütlerine göre yazılmış kitaplar okumalarının onların kitap okuma alışkanlığını olumlu yönde etkileyebileceği dikkate alındığında öğretmenlerin kitap tavsiye ederken bu ölçütleri ne derece kullandıklarının önemi de ortaya çıkmaktadır. Bu çalışma farklı öğrenim düzeylerindeki öğrencilere Türkçe eğitimi veren öğretmenlerin kitap tavsiye ederken kullandıkları ölçütleri ortaya koyması sebebiyle sınıf öğretmenlerinin, Türkçe öğretmenlerinin ve Türk dili ve edebiyatı öğretmenlerinin kitap tavsiye etme yaklaşımlarını da karşılaştırma imkânı sunmaktadır.

Gerçekleştirilen alan yazın taraması sonucunda sınıf, Türkçe ve Türk dili ve edebiyatı öğretmenlerinin görüşlerine başvurularak öğretmenlerin öğrencileri için kitap seçmede göz 
önünde bulundurdukları ölçütleri ortaya koyan, bu ölçütleri çocuk edebiyatı ölçütleri çerçevesinde inceleyen bir araştırmaya ulaşılamamıştır. İşbu araştırma, alandaki bu boşluğun doldurulmasına hizmet etmesi sebebiyle de önemli bir çalışmadır.

Bu çalışmada, sınıf, Türkçe ve Türk dili ve edebiyatı öğretmenlerinin öğrencilerine kitap önerirken dikkat ettikleri ölçütlerin ortaya çıkarılması ve bu ölçütlerin çocuk edebiyatının temel ilkeleri bağlamında incelenmesi amaçlanmaktadır. Bu amaca yönelik olarak aşağıdaki araştırma sorularına cevap aranmıştır:

1. Sınıf, Türkçe ve Türk dili ve edebiyatı öğretmenleri öğrencilerine kitap önerirken çocuk edebiyatının temel ölçütlerinden hangilerini ne ölçüde kullanmaktadırlar?

2. Sınıf, Türkçe ve Türk dili ve edebiyatı öğretmenleri öğrencilerine kitap önerirken çocuğa görelik ve çocuk gerçekliği ilkelerini ne ölçüde kullanmaktadırlar?

3. Sınıf, Türkçe ve Türk dili ve edebiyatı öğretmenleri öğrencilerinin en çok hangi türleri okuması gerektiği kanaatindedirler?

\section{Yöntem}

\section{Araştırmanın Modeli}

Bu çalışmada Temel Nitel Araştırma deseni kullanılmıştır. Merriam’e (2009) göre temel nitel araştırma deseni kullanan araştırmacılar şu üç konuya odaklanırlar: insanların bir konudaki deneyimlerini nasıl yorumladıklarına; dünyalarını nasıl inşa ettiklerine; ve deneyimlerine ne anlamlar yüklediklerine (s. 23). Bu tür çalışmalarda genel amaç insanların yaşantılarını ve deneyimlerini nasıl anlamlandırdıklarını anlamaktır. Veriler; görüşme, gözlem ya da doküman inceleme yoluyla toplanabilir. Temel nitel araştırmalar günümüzde eğitim araştırmalarında yaygın olarak kullanılmaktadır. Bu çalışmada da temel nitel araştırma deseni kullanılarak öğretmenlerin öğrencilere kitap önerirken nelere dikkat ettiklerini kendi deneyimleri üzerinden paylaşmaları ve bu konudaki görüşlerini aktarmaları istenmiştir.

\section{Varsayım ve Sinirlılıklar}

$\mathrm{Bu}$ araştırmada elde edilen verilerden yola çıkılarak ulaşılan bulgu ve sonuçlar; araştırmaya katılan 15 öğretmenin görüşme sorularına verdikleri cevaplar ile sınırlıdır. Öğretmenlerin sorulara içten ve dürüst cevaplar verdikleri varsayılmaktadır.

\section{Çalışma Grubu}

Sınıf öğretmeni, Türkçe öğretmeni ve Türk dili ve edebiyatı öğretmenlerinin öğrencilerine kitap önerirken göz önünde bulundurdukları ölçütleri ortaya çıkarmak ve bu ölçütleri çocuk edebiyatının temel ölçütleri açısından değerlendirmek amacıyla gerçekleştirilen bu araştırma her branştan 5 öğretmen olmak üzere toplam 15 öğretmen ile gerçekleştirilmiştir. Öğretmenlerden 7 tanesi amaçlı örneklem türlerinden kolay ulaşılabilir örneklem yöntemi ile araştırmacının kendi iş çevresinden tanıdığı öğretmenlerden seçilmiştir. Geriye kalan 8 öğretmen ise kartopu örneklem yöntemi kullanılarak daha önce görüşülmüş olan öğretmenlerin tavsiye ettiği öğretmenlere e-posta ile ulaşılarak çalışmaya katılmaya gönüllü olanlar arasından seçilmiştir. Araştırmaya katılan öğretmenlere ilişkin demografik bilgiler Tablo 1, Tablo 2 ve Tablo 3'te sunulmuştur. 
Öğretmenlerin Kitap Önerisinde Kullandıkları Ölçütlerin Çocuk Edebiyatının Temel İlkelerine Göre İncelenmesi Examining the Criteria Used by Teachers in Suggesting Books Based on the Main Principles of Children's

\section{Tablo 1}

Araştırmaya katılan ögretmenlere ilişskin demografik bilgiler - sını ögretmenleri

\begin{tabular}{llll}
\hline & Cinsiyet & Meslekî Deneyim & Eğitim Durumu \\
\hline Sınıf Öğretmeni -1 (SÖ1) & E & 20 yıl ve üstü & Lisans \\
Sınıf Öğretmeni -2 (SÖ2) & E & 20 yıl ve üstü & Lisans \\
Sınıf Öğretmeni -3 (SÖ3) & E & 20 yıl ve üstü & Lisans \\
Sınıf Öğretmeni -4 (SÖ4) & E & 20 yıl ve üstü & Lisans \\
Sınıf Öğretmeni -5 (SÖ5) & K & $15-20$ yıl & Lisans \\
\hline
\end{tabular}

\section{Tablo 2}

Araştırmaya katılan öğretmenlere ilişkin demografik bilgiler - Türkçe öğretmenleri

\begin{tabular}{llll}
\hline & Cinsiyet & Meslekî Deneyim & Eğitim Durumu \\
\hline $\begin{array}{l}\text { Türkçe Öğretmeni -1 } \\
\text { (TÖ1) }\end{array}$ & $\mathrm{K}$ & $5-10$ yıl & Lisans \\
$\begin{array}{l}\text { Türkçe Öğretmeni -2 } \\
\text { (TÖ2) }\end{array}$ & $\mathrm{K}$ & $10-15$ yıl & Lisans \\
$\begin{array}{l}\text { Türkçe Öğretmeni -3 } \\
\text { (TÖ3) }\end{array}$ & $\mathrm{E}$ & $5-10$ yıl & Lisans \\
$\begin{array}{l}\text { Türkçe Öğretmeni -4 } \\
\text { (TÖ4) }\end{array}$ & $\mathrm{K}$ & $5-10$ y1l & Yüksek Lisans \\
$\begin{array}{l}\text { Türkçe Öğretmeni -5 } \\
\text { (TÖ5) }\end{array}$ & $\mathrm{E}$ & $5-10$ yıl & Yüksek Lisans \\
\hline
\end{tabular}

Tablo 3

Araştırmaya katılan öğretmenlere ilişskin demografik bilgiler - Türk dili ve edebiyatı öğretmenleri

\begin{tabular}{llll}
\hline & Cinsiyet & Meslekî Deneyim & Eğitim Durumu \\
\hline $\begin{array}{l}\text { Türk Dili ve Edebiyat1 } \\
\text { Öğretmeni -1 (TDEÖ1) }\end{array}$ & $\mathrm{K}$ & $5-10$ yıl & Lisans \\
$\begin{array}{l}\text { Türk Dili ve Edebiyat1 } \\
\text { Öğretmeni -2 (TDEÖ2) }\end{array}$ & $\mathrm{E}$ & 20 yıl ve üstü & Lisans \\
$\begin{array}{l}\text { Türk Dili ve Edebiyat1 } \\
\text { Öğretmeni -3 (TDEÖ3) }\end{array}$ & $\mathrm{K}$ & $5-10$ yıl & Lisans \\
$\begin{array}{l}\text { Türk Dili ve Edebiyat1 } \\
\text { Öğretmeni -4 (TDEÖ4) }\end{array}$ & $\mathrm{K}$ & $0-5$ yıl & Yüksek Lisans \\
$\begin{array}{l}\text { Türk Dili ve Edebiyat1 } \\
\text { Öğretmeni -5 (TDEÖ5) }\end{array}$ & $\mathrm{E}$ & $10-15$ yıl & Yüksek Lisans \\
\hline
\end{tabular}

\section{Veri Toplama Aracı}

Görüşme; insanların bir olay ya da olguya ilişkin bakış açılarının, duygu ve düşüncelerinin ortaya çıkarılması ve yorumlanması amacıyla gerçekleştirilir. Genellikle bir kişi ya da grupla, belli bir amaca yönelik olarak gerçekleştirilen söyleşiler biçiminde gerçekleşir. Görüşme tekniğinde yapılandırılmış, yarı yapılandırılmış ve yapılandırılmamış görüşme formları kullanılarak kişilerin görüşleri alınır (Merriam, 2009). İnsanların bir konu ya da durum hakkında görüşlerini, tecrübelerini, duygularını ya da değerlendirmelerini paylaşabildikleri 
görüşme yönteminde araştırmacı birinci elden kaynağa ulaşmış ve konuya ilişkin detaylı bilgiye ulaşmış olur. $\mathrm{Bu}$ araştırmada da veri toplama tekniği olarak görüşme tekniği kullanılmış, bu amaçla araştırmacılar tarafından geliştirilen yarı yapılandırılmış görüşme formu ile veriler elde edilmiştir.

Araştırma sonuçlarının dayandırıldığı verilerin tamamı araştırmacılar tarafından geliştirilen ve araştırmanın problem ve alt problemleriyle ilişkili 12 adet açık uçlu sorudan oluşan yarı yapılandırılmış görüşme formu ile elde edilmiştir.

Form hazırlanmadan önce alan yazın taraması gerçekleştirilerek ön deneme soruları elde edilmiştir. Sorular üç Türkçe öğretmeni ve iki öğretim üyesinin görüşüne sunulmuştur. Uzman görüşlerinde bazı soruların görüşmeciyi sınırlandırıcı unsurlar içerdiği belirtilmiştir. Örneğin uzmanlara gönderilen görüşme sorularının dört tanesinde “...üç olumsuzluk nedir?”, “...üç özellik nedir?” gibi sınırlandırıcı ifadeler var iken, bu ifadeler uzman görüşlerine uygun olarak çıkarılmış ve “...olumsuzluklar nelerdir?”, “...özellikler nelerdir?” şeklinde yeniden düzenlenmiştir. Ardından görüşme sorularının anlaşılırlığının sınanması amacıyla sorular bir sınıf, bir Türkçe ve bir Türk dili ve edebiyatı öğretmenine yöneltilmiştir. Soruların anlaşılır olduğu görülmüş ve görüşme formuna son hâli verilmiştir. Yarı yapılandırılmış görüşme formu şu soruları içermektedir:

1) Öğrencilerinizi okuma alışkanlığı bakımından nasıl değerlendirirsiniz?

2) Okuma alışkanlığ gelişmiş bir öğrenciyi okuma alışkanlığg gelişmemiş bir öğrenciden ayıran özellikler sizce nelerdir?

3) İyi bir çocuk kitabını kötü bir çocuk kitabından ayıran özellikler sizce nelerdir?

4) Öğrencilerinize kitap önerisinde bulunacak olsaydınız hangi kitapları önerirdiniz?

5) Çocuk kitaplarında en çok önemsediğiniz özellikler nelerdir?

6) Çocuk kitaplarında en sık karşılaştığınız olumsuzluklar nelerdir?

7) Sizce bir çocuk kitabı, okuruna neler kazandırmalıdır?

8) Öğrencilerinizin okuduğu çocuk kitapları arasında en sık karşılaştığınız kitaplar hangileridir?

9) Öğrencilerinizin kitap tercihlerini belirleyen özellikler sizce nelerdir?

10) Sizce, iyi bir okuyucu olabilmek için hangi tür kitaplar bu yaşlarda mutlaka okunmalıdır?

11) Kitap okumak bir mezuniyet şartı olsaydı öğrencilerinizin hangi kitapları okumuş olarak mezun olmalarını isterdiniz?

12)Kitap önerirken göz önünde bulundurduğunuz kriterleri önem derecesine göre sıralamak isteseydiniz nasıl bir tablo ortaya çıkardı?

\section{Veri Toplama Süreci}

Araştırma, Uşak Üniversitesi Sosyal ve Beşeri Bilimler Bilimsel Araştırma ve Yayın Etiği Kurulunun 10.06.2021 tarih ve 2021-127 sayılı kararı ile etik açıdan uygun bulunmuştur. Geliştirilen veri toplama aracı ile gerçekleştirilen görüşmeler çevrimiçi ortamda Google Meet platformu üzerinden yapılmıştır. Araştırmacılar tarafından yapılan ve her biri ortalama 30 
dakika süren çevrimiçi görüşmeler katılımcıların sözlü rıza beyanı alınarak ses kaydı biçiminde kayıt altına alınmış, ardından da yazılı olarak raporlanmıştır.

\section{Veri Analizi}

Yazıya aktarılmış olan görüşmelerin çözümlenmesinde betimsel analiz yöntemine başvurulmuştur. Betimsel analizde, toplanan verilerde yer alan araştırma problemleri ile ilişkili ifadeler, alan yazından çekilen temalar ve temaların altında yer alan kodlar ile çözümlenmektedir (Yıldırım ve Şimşek, 2018). Aslında betimsel analiz tümdengelim yaklaşımını benimsemektedir. Tümdengelim yaklaşımında, veri analizine geçilmeden alanyazın taraması ile temalar ve kodlar oluşturulmakta daha sonra bu kodlarla veri çözümlenmektedir (Merriam, 2009). Bu çalışma da tümdengelim yaklaşımı ile çözümleme yapmayı gerektirmektedir çünkü bu çalışmada öğretmenlerin öğrencilere kitap tavsiye ederken hali hazırda alan yazında yer alan çocuk edebiyatının temel ölçütlerini ne düzeyde kullandıkları tespit edilmektedir. Bu sebeple, öncelikle birinci alt problem için çocuk edebiyatının temel ölçütleri alan yazından çekilerek listelenmiş (Biçim, içerik, dil ve anlatım, eğitsel öğeler) ve her bir ölçüt tema kabul edilerek bu temaların alt kodları oluşturulmuştur. Daha sonra öğretmenlerin görüşme sorularına verdikleri cevaplar bu kodlarla kodlanarak veri çözümlenmiştir. Aynı uygulama ikinci alt problem için çocuğa görelik ve çocuk gerçekliği ilkeleri tema kabul edilip alt kodları oluşturularak; üçüncü alt problem için ise kitap türleri başlığı tema kabul edilip her bir kitap türü de kod olarak ele alınarak gerçekleştirilmiştir. Öğretmenlerle yapılan çevrimiçi görüşmelerden sonra elde edilen veriler, her iki araştırmacı tarafından da birbirinden bağımsız olarak kodlanmış, kodlamalarda güvenirliğin sağlanması için veri analizi süreci tamamlandıktan sonra araştırmacılar bir araya gelerek analizlerini karşılaştırmışlar ve görüş birliğine varıldıktan sonra bulgular raporlanmıştır (Merriam, 2009, s. 216).

\section{Geçerlik ve Güvenirlik Çalışmaları}

Çalışmanın görüşme formu hazırlanırken, yukarıda da belirtildiği gibi, üç öğretmen ve iki öğretim üyesi olmak üzere toplam beş alan uzmanından görüş alınmış, bir sınıf öğretmeni, bir Türkçe öğretmeni ve bir de Türk dili ve edebiyatı öğretmeni ile de pilot uygulamalar yapılarak görüşme sorularının kapsam geçerliği sağlanmıştır. Katılımcıların tamamından yazıya dökülmüş görüşlerin kendi görüşlerini yansıttığı cevabı alınmıştır (Merriam, 2009, s. 217). Bu çalışmada aktarılabilirlik (Merriam, 2009, s. 221) ilkesine uygun olarak çalışmanın katılımcıları hakkında demografik bilgiler paylaşılmış, çalışmanın tüm aşamalarına detaylı bir şekilde yer verilmiş ve çalışmanın bulguları katılımcıların kendi ifadeleri ile sunulmuştur. Araştırmanın veri toplama ve veri analizi süreci de güvenilebilirlik (Merriam, 2009, s. 210212) ilkesi gereğince detaylı bir şekilde ifade edilmiş, veri analizi iki farklı araştırmacı tarafından bağımsız bir şekilde gerçekleştirildikten sonra bir araya gelinerek yapılan analizler üzerinde görüş birliği sağlanmıştır. Onaylanabilirlik ilkesi gereğince katılımcılarla gerçekleştirilen görüşmeler ses kaydına alınmıştır ve araştırmacılar tarafından saklanmaktadır. 


\section{Bulgular ve Yorumlar}

Öğretmenlerle gerçekleştirilen görüşmeler sonucunda elde edilen verilerin analiz edilmesiyle ulaşılan bulgular, araştırma sorularına cevap olacak nitelikteki verilere dayanılarak yorumlanmıştır.

\section{Birinci Alt Probleme İlişkin Bulgular ve Yorum}

"Sınıf, Türkçe ve Türk dili ve edebiyatı öğretmenleri öğrencilerine kitap önerirken çocuk edebiyatının temel ölçütlerinden hangilerini ne ölçüde kullanmaktadırlar?” biçiminde tanımlanan birinci alt probleme ilişkin öğretmen görüşleri incelenerek öğretmenlerin kitap önerisinde bulunurken göz önünde bulundurdukları temel ölçütler Tablo 4'te gösterilmiştir.

\section{Tablo 4}

Öğretmenlerin kitap önerisinde bulunurken göz önünde bulundurdukları ölçütlerin sınıflandırılması

\begin{tabular}{lllll}
\hline & Sinıf Öğr. & Türkçe Öğr. & $\begin{array}{l}\text { Türk Dili ve } \\
\text { Edebiyatı Öğr. }\end{array}$ & Toplam \\
\hline $\begin{array}{l}\text { Biçim (boyut, kapak } \\
\text { ve cilt, sayfa düzeni, } \\
\text { harfler, görseller) }\end{array}$ & 4 & 2 & 1 & 7 \\
\hline $\begin{array}{l}\text { Içerik (konu, izlek, } \\
\text { ileti, plan, karakter) }\end{array}$ & 5 & 4 & 2 & 11 \\
\hline Dil ve Anlatım & 4 & 4 & 4 & 12 \\
\hline Ĕ̈itsel Ögeler & 5 & 5 & 5 & 15 \\
\hline
\end{tabular}

Tablo 4 incelendiğinde öğretmenlerin kitap önerisinde bulunurken göz önünde bulundurdukları ölçütler arasında en çok eğitsel unsurların ön plana çıktığı anlaşılmaktadır. Öğretmenler, öğrencinin zihinsel, duygusal gelişimine katkıda bulunacak eserlerle karşılaşmaları gerektiğini düşünmektedirler. Eğitsel unsurlara ilişkin her branştan öğretmenlerin görüşlerinden örnek mahiyetindeki alıntılara aşağıda ulaşılabilir:

Hayal gücü, empati, yorumlama, üretme, doğa ve insan sevgisi vb. değerleri içermelidir. Üretme, paylaşma, iletişim ön planda tutulmalıdır. Sonuç bölümü mutlaka olumlu mesajlar üretmelidir. Evrendeki tüm canlıların ortak yaşamına birlikteliğine yardımlaşmasına önem vermelidir. Fabl türü zengin olmalıdır (SÖ5, 03.05.2021).

Hayal gücünü geliştirmeli. Ben hayal gücünün çok önemli olduğunu düşünürüm hep. Çocuk hem hayal etmeli hem de yeni deneyimler elde etmeli kitaplar sayesinde. Yeni şeyler öğrenmeli. Bence hem çocuğu zihnen doyurup hem de hayal kurmasını sağlamak gerek kitaplar yoluyla. Bir de artık devir değişti, televizyonlar şiddet ve olumsuz şeylerle dolu. Çocuğu kitaplarla iyiye yönlendirmeli, çocuk kitaptan iyiyi doğruyu öğrenmeli (TÖ1, 26.04.2021).

Kişilik kazandıracak, düşünmeye sevk edecek, eleştiri yeteneği kazandıracak eserler olmasına dikkat ederdim. Lise çağında karakter gelişimi çok önemli. Zihinsel gelişimin yanında karakter gelişimini desteklemek gerek (EÖ2, 01.06.2021).

Öğretmenlerin kitap önerisinde bulunurken göz önünde bulundurdukları ölçütleri incelemek amacıyla oluşturulan Tablo 4'te görüldüğü üzere; tüm branşlarda öne çıkan ikinci 
ölçüt alanı, eserin dil ve anlatımıdır. Öğretmenlerin görüşme sorularına verdikleri cevaplar incelendiğinde dil bakımından sadelik ve anlaşılılık; anlatım bakımından ise akıcılık ve sürükleyicilik özelliklerinin ön planda olduğu görülmüştür.

Ben önceliği dil ve üsluba veririm. Sonrasında güçlü ve ilgi çekici bir kurgu ararım. Elbette verdiği mesajlar da önemli. Yani olmadık örtük mesajlar verdiğini fark edersem öğrencime okutmam (SÖ2, 04.05.2021).

Bir kere dilinin akıcı olması. En soyut, en karmaşık konu bile dil akıcı net anlaşılır olduktan sonra çocuklar kavriyor. Anlayamadıkları noktalarda öğretmene geldiklerinde öğretmenin küçük dokunuşuyla o kafa karışıklığı giderilebiliyor. Basit bir olaya dönük bir hikayeyse bu, hikayesi varsa çok basit bir olayda bile eğer karmaşık anlatıldıysa çocuk işin içinden çıkamıyor. Betimlemelerin çok uzun olmaması gerekiyor bir kere. Dil yalın sade akıcı olmalı. Böyle olursa her kitap çocuklar için faydalı olur (TÖ5, 26.04.2021).

Bir kere, yukarıda da dediğimden yola çıarak dili ve anlatımı öğrenciye okuduğunu anlama imkânı vermeli. Yani çocuk okuduğunu anlamaya çalışırken aşırı bir zorlukla karşılaşmamalı. Gelişmeli ama aşırı zorlanmamalı. Hayal gücü gelişmeli. Merak duygusunu hep canlı tutmalı. Baştan sona merak etmeli çocuk (EÖ1, 01.06.2021).

Tablo 4 incelendiğinde öğrencilerin yaş/sınıf seviyesi yükseldikçe çocuk edebiyatı ürünlerinin biçim ve içerik unsurlarının öğretmenler tarafından daha az önemsendiği anlaşılmaktadır.

Biçimsel özelliklerin sınıf öğretmenleri tarafından daha fazla önemsendiği cevaplarından anlaşılmaktadır. $\mathrm{Bu}$ durum, çocuk edebiyatı biliminde de önerilen bir yaklaşımdır. Okul öncesi ve ilkokul yıllarında kitaplardaki görseller, yazı puntosu, kitapların yaş ve gelişim düzeyine uygun büyüklükte olması gibi biçimsel özellikler ön plana çıkmaktadır. Gerek kenar boşluklarına gerek satır arası boşluklarına gerekse metnin ve resmin sayfadaki yerleşimine dikkat edilmeli, sayfa düzeni hem çocuklarda estetik bir zevk oluşturmalı hem de rahat okunabilecek şekilde tasarlanmalıdır. Harflerin büyüklükleri de kitabın hitap ettiği yaş grubuna göre ayarlanmalıdır (Arıkan ve İnce Samur, 2020). Bir sınıf öğretmeninin vermiş olduğu şu cevap, bu bulguyu somutlaştırması bakımından örnek olarak alınmıştır:

Konusunun çocukların ilgisini çekebilecek, görselleri olan kitapları tercih ederim. Görseller ilkokulda çok önemli. Kitapta yazanlardan daha önemli olabiliyor bazen görseller. (...) Kitabın görsellerle süslenmiş olması ve puntosunun çocuğa uygunluğu. Biliyorsunuz 13 punto uygundur. Çocuğa kazandırabileceği duygu ve davranışlar var $\mathrm{m} ı$ buna bakarım. Bir de çocukta yazma hevesini teşvik edecek kitaplar seçerim (SÖ4, 04.05.2021).

Yazıcı Okuyan'ın (2009) sınıf ve Türkçe öğretmenlerine yönelik anket araştırmasına katılan öğretmenlerin \%98,5'inin kitapların dil ve anlatım özelliklerine dikkat ettiğini belirtmiş olmaları da bu bulguları destekler niteliktedir.

Akıcılık çok önemli. Zaten çocuklar çok zor geçiyor kitabın başına. Onu kitaba bağlayacak akıı bir anlatımı olmalı. Sıkıcı, tek düze bir anlatım ilgilerini çekmeyen 
bir konuyla birleşince kitaptan kaçıyor çocuk. Tabii bunu yaparken bir şeyler de kazandırmalı. Bomboş kitaplar önermeyi doğru bulmuyorum. Yani sırf eğlenceli, akıcı diye bir kitap önermek doğru değil (EÖ4, 01.06.2021).

Dil ve üslup bence en önemli ayırıcı özellik. Anlatımı dikkati çekebiliyorsa, gençlerin dünyasında bir etkisi oluyorsa çocuk okuyor kitabı. Değilse atıyor kenara (EÖ1, 01.06.2021).

Türk dili ve edebiyatı öğretmenlerinin cevapları incelendiğinde içerik başlığının çocuk edebiyatı ürünlerinde en az önemsenen unsur olduğu anlaşılmakta; bunun sebebinin ise artık öğrencilerin yaş ve gelişim düzeyi bakımından kitaplardaki estetik yapının, dil ve üslûbun öne çıkışı ile ilgili olduğu düşünülmektedir.

Sınıf öğretmenlerinin cevapları incelendiğinde kitaplardaki görsel kullanımındaki eksiklik ve yanlışlıklar ile kullanılan dilin açık ve anlaşılır olmaması, özellikle eleştirilmektedir.

Görsellere çok önem verdiğimi anlamışsınızdır. Görselleri kötü olan kitaplarla karşılaştığım zaman çok rahatsız oluyorum. Bu tür kitaplar ne yazık ki çok arttı. Bir de anlaşılır yazmıyorlar, çocuklar için çocuklara göre yazmıyorlar (SÖ1, 03.05.2021).

Kitaplardaki kullanılan dilin sade ve anlaşılır olmaması. Görselliğin az olması, anlama ve yorumlamaya zenginlik katmaması. Hayallerin umutsuz, gerçekleşmeyecek biçimde öykülenmesi. Giriş, gelişme ve sonuç bölümlerinin birbirini tamamlamaması, kopukluk. Sanki hazırlanıp gelmişim gibi değil mi öğretmenim (SÖ2, 04.05.2021)?

Kitaplardaki dilin açık ve anlaşılır olmamasının yanında argo sözlerin kullanılması da sınıf öğretmenleri tarafından fark edilen olumsuzluklardan biri olarak öne çıkmaktadır.

Dar bir kelime hazinesi var özellikle yeni nesil çocuk kitaplarında. Bir de çok sık karşılaşıyoruz, artık çocuk kitaplarına çok fazla argo sözcükler var. Bir de ne yazık ki çocuk zihinleri dinî hurafelerle zedeleyecek bazı kitaplarla da karşılaşıyoruz (SÖ2, 04.05.2021).

Kötü sözcükler, hurafelerle doldurulmuş hikâyeler, kötü örnek oluşturan karakterler... En başta bunların temizlenmesi lazım (SÖ3, 04.05.2021).

Türkçe öğretmenlerinin bu konudaki görüşleri; argo ve küfür kullanımı, yaşa uygun olmayan içerik ve düzeye uygun olmayan dil kullanımında birleşmektedir. Sınıf öğretmenlerinin cevapları ile birlikte değerlendirildiğinde bu bulgu hem yayıncıların hem yazarların hem de çocuğun eğitiminde rol alacak olan herkesin dikkatini çekmesi gereken önemli bir bulgudur.

Çocukların baştan sona zevkle, merakla okuyacağı kitap sayısının az olması, küfür ya da argo söz içermesi... Bir de çeviri kitaplardaki yabancı isimlerin yarattığı sıkıntı. Çocuk çok fazla yabancı isim görünce okuduğunu anlamıyor ki (TÖ1, 26.04.2021).

Bir kere yaşlarına uygun olmayan kitaplar moda diye okunuyor. İçeriği hiç uygun değil mesela yaşlarına ama okumak istiyorlar. Kelime kullanımı çok ağır oluyor, hiç bilmedikleri bir sürü kelime kullanılıyor. Bunun belli bir oranı olmalı kitaplarda. Bir de yetkin olmayan yayınevleri bilgisizce davranıp yazı boyutunu doğru seçemiyor (TÖ2, 26.04.2021). 
İdeolojik yaklaşım ile yazarın kendi görüşlerini ya da bir erdemi doğrudan dikte etmesine ilişsin eleştiriler de Türkçe öğretmenlerinin dile getirdiği görüşler arasındadır.

En önemlisi bence... Hayal gücünü geliştirmek, benim için bir kitapta olması gereken ilk özelliktir. Çocuğun hayatında, düşüncesinde bir şeyler değişmeli kitabı okuduğunda. Hayata bakışını değiştirmeli. Çocuğun yaşamına dokunmalı. Diğeri, kelime dağarcığını geliştirmesi... Mesaj kaygısı olmamalı bence bir kitapta, yani... Bir mesaj vermesi değil de çocuğun hayal gücünü derinleştirmesi... Ne bileyim sürekli bir değerler eğitimi dayatması, belki biraz polemik ama bilmiyorum, konuyla ilgili bulur musunuz? Ben değer ya da mesaj kaygısı istemiyorum bir çocuk kitabından hocam özetle. Yaratıcılık önemli hocam, çocuğun yaratıc1lı̆̆ gelişsin, kitabı sevsin. Sorgulama becerisi gelişsin. Tabii ki her kitapta bir mesaj vardır ama göze parmak sokar gibi değil de daha sanatsal, daha alt metinlerle, daha edebi yönü olacak tabii bir kitabın elbette (TÖ3, 26.04.2021).

Çocuğa bir şeyler öğretme kaygısı. Az önce bahsetmiştim, göze parmak sokarcasına... Yazarın kendi fikirlerini çocuklara benimsetmeye çalışması, empoze etmeye çalışması... Kitaptaki konuların, temaların çocuklara uygun olmaması ve bazı çocuk kitaplarının denetimden geçmeden basılması. Ne yazık ki günümüzde artık ticari sebeplerle çok fazla çocuk kitabı basılıyor ve bu kitapların büyük bir bölümü denetimden geçmiyor. Hatırlarsanız bir ara internette, sosyal medyada oldukça konuşulmuştu. Bir Keloğlan kitabındaki tecavüz meselesinin ele alınması gerçekten korkunçtu (TÖ4, 26.04.2021).

En sık karşılaştı̆̆ım olumsuzluk, yazarın kendi ideolojisini -bize uyar ya da uymaz, ben onu tartışmıyorum problem değil kesinlikle o- kişiler üzerinden, olaylar üzerinden empoze etmeye çalışması. Yüceltmesi o düşünceyi bir karakter üzerinden. Bu bazı kitaplarda çok bariz belli oluyor (TÖ5, 26.04.2021).

Sınıf öğretmenlerinin ve Türk dili ve edebiyatı öğretmenlerinin cevaplarında da bu bulguyu destekler şekilde kitaplarda yer verilen hurafelere ve ideolojik yaklaşıma yönelik eleştiriler görülmüştür. Bu bulgu da eğitimin ve yayıncılığın tüm unsurlarınca dikkate alınması gereken bir bulgu olarak görülmelidir:

En sık karşılaşılan bir durum olmasa da cinsel içerikli küfür ve sözlere yer verilmesi çocuk kitaplarındaki olumsuz özelliklerin başında. Bunun dışında ön yargı, kör inanç ve ötekileştirici tavır... Batıl inançlar... (TDEÖ3, 01.06.2021)

İdeolojisini çok fazla yansıtan kitaplarla karşılaşıyoruz. Göze parmak sokarcasına ideolojiyi aşılamak istiyor. Çok kalitesiz kitaplar bunlar. Yazmış olmak için yazan yazarlar, sayfa doldurmak için yazılan kitaplar... Aynı olaylar, aynı cümleler sürekli tekrarlanıyor. Çocuğun takip edemeyeceği kadar uzun cümleler oluyor. (TDEÖ5, 07.06.2021)

Nitekim Yazıcı Okuyan (2009)'un anket çalışmasında da öğretmenlerin \%81,8'i okudukları kitapların çocukları belli bir ideolojik anlayışa yöneltmemesine dikkat ettiklerini ifade etmişlerdir. Bu hâlde, öğretmenlerin, çocuk edebiyatı ürünlerinin yetişkin ideolojilerini empoze etmede bir araç olarak görülmemesi gerektiği kanaatinde birleştikleri âşikârdır. 


\section{İkinci Alt Probleme İlişkin Bulgular ve Yorum}

Okuma alışkanlığı okul, aile, akranlar ve öğrencinin aktif rol oynaması gereken, her branştan öğretmenin sorumluluk hissetmesi gereken bir eğitim kazanımıdır ancak okuma beceri ve alışkanlığının en çok vurgu kazandığı branşlar olarak düşünüldüğünde sınıf, Türkçe ve Türk dili ve edebiyatı öğretmenliği branşları bu araştırmada araştırma grubunda yer almışlardır. "Sınıf, Türkçe ve Türk dili ve edebiyatı öğretmenleri öğrencilerine kitap önerirken çocuğa görelik ve çocuk gerçekliği ilkelerini ne kadar kullanmaktadırlar?" şeklinde tanımlanan ikinci alt probleme ilişkin bulgular öğretmenlerin görüşleri incelenerek alan yazın taramasından yola çıkılarak açıklanan ilke ve özelliklere göre tablolaştırılmıştır.

Tablo 5

Çocuğa görelik ve çocuk gerçekliği ilkelerine göre cevapların dă̆llımı

\begin{tabular}{llll}
\hline & & Çocuğa Görelik & Çocuk Gerçekliği \\
\cline { 2 - 3 } Sınıf Öğretmenleri & 5 & 2 \\
Türkçe Öğretmenleri & 5 & 2 \\
Türk Dili ve & Edebiyatı & 5 & 2 \\
Öğretmenleri & & & 6 \\
\hline Toplam & 15 &
\end{tabular}

Araştırma problemlerine cevap aramak amacıyla sorulan görüşme sorularına öğretmenlerin verdikleri cevaplar incelendiğinde tüm branşlarda öğretmenlerin çocuğa görelik ilkesine ilişkin cevaplar verdikleri görülmüştür. Çocuk gerçekliği ilkesine atıfta bulunan birtakım cevaplar olsa da bu ilkenin daha az göz önünde bulundurulduğu anlaşılmaktadır.

Çocuk kitapları çocuğun yaş ve seviyesine uygun olmalı, yaşadığı çevreye ve yurduna ait sorunlara sahip çıkmaya paralellik göstermelidir. Konuya ait olaylar zinciri, çocuğun anlama ve yorumlama değerlerine uyum sağlamalıdır. Çocukların kişisel yeteneklerini analiz ederek hangi kitaplardan hoşlanacağının ön hazırlığı yapılmalıdır. Görselleri zengin olmalıdır. Mutlaka ilerisi için olumlu hedef ve mesaj içermelidir. Her yıl yeni çıkan kitaplardan seçim yaparım. Aslında şu an aklıma gelen bir şey yok. Belki Çetin Ceviz'i söyleyebilirim. Fabl türünü önemsiyorum. Bazıları eleştiriyor ama La Fontaine'i hâlâ öneririm (SÖ5, 03.05.2021).

İyi bir çocuk kitabı biçim ve içerik yönünden çocuğa görelik ilkesini taşıyabilmeli. Biçim olarak yaş seviyesine uygun biçimsel özelliklere sahip olabilmeli. Punto, resim seçimi, kâğıt seçimi gibi. İçerik meselesi ise tabii ki biçimden çok daha önemli bir konu. İçerik yönünden çocuğa göre olabilmesi için bir kitabın kurgu, konu, tema, anlatım ve dil, üslup gibi birbirinden çok farklı konularda incelenebilir. Her şeyden önce bir çocuk kitabı öğretici olmak zorunda değil. Çocuğa ders verme niteliğindeki kitaplar, çocuğa neyin doğru olduğunu dikte ettiren kitaplar iyi çocuk kitapları değildir. Sürekli öğretici şeyler okusak biz yetişkinler için de oldukça sıkıcı olurdu değil mi? İyi bir çocuk kitabı kendi fikirlerini çocuğa benimsetmeye çalışan kitaplar değildir. İyi bir çocuk kitabı evrensel değerleri çocuğa hissettiren ve sezgi yoluyla evrensel değerleri çocuğa hissettiren kitaplardır. Sedat Sever hocamız bu konuda şöyle söyler: "Bir çocuk kitabı çocuğun zihnine, ruhuna ve yüreğine hitap etmelidir." Öğreticilik kaygısı taşıyan kitapların kötü olduğunu düşünüyorum ben de. Ayrıca iyi 
bir çocuk kitabı çocuğa okuma zevkini tattırabilmelidir. Çocuklar küçük yaşlardan itibaren edebi zevki onlara tattıran kitaplarla tanıştıklarında okumak da onlar için bir alı̧skanlık hâline gelecektir (TÖ4, 26.04.2021).

Öğrencinin yaşına ve ilgisine uygunluk, sıkılmadan okuyabilmesi, bilgi sahibi olabilmesi... Yaş düzeylerine uygun konu, dil ve üslup. Hayal gücünü geliştirmeli. Anlatımı canlı olmalı, akıcı ve anlaşılır olmalı (TDEÖ1, 01.06.2021).

Tablo 5 aracılığıyla açıklanan araştırma bulgularına örnek olması bakımından her branştan öğretmenin görüşlerine de yukarıda yer verilmiştir. Bu bulgulardan yola çıkılarak öğretmenlerin öğrencilerine kitap önerisinde bulunurken en çok göz önünde bulundurdukları ilkenin çocuğa görelik ilkesi olduğu anlaşılmaktadır.

\section{Ü̧̧üncü Alt Probleme İlişkin Bulgular ve Yorum}

"Sınıf, Türkçe ve Türk dili ve edebiyatı öğretmenleri öğrencilerinin en çok hangi türleri okuması gerektiği kanaatindedirler?" biçiminde tanımlanan üçüncü alt probleme ilişkin bulgular, gerek öğretmenlerin doğrudan türe yönelik cevaplarından gerekse tavsiye ettikleri kitaplardan yola çıkılarak yorumlanmıştır. Tablo 6'da görüldüğü gibi roman ve öykü türlerini 10 öğretmen, masal türünü 6 öğretmen, fabl türünü 2 öğretmen, deneme, şiir, fikra ve bilmece türlerini de 1'er öğretmen tavsiye etmiştir.

\section{Tablo 6}

Öğretmenlerin öğrencilere tavsiye ettiğ kitap türleri

\begin{tabular}{lllllllll}
\hline & Roman & Öykü & Masal & Fabl & Deneme & Şiir & F1kra & Bilmece \\
\cline { 2 - 8 } Sinıf Öğretmenleri & 0 & 5 & 3 & 2 & 0 & 1 & 0 & 0 \\
$\begin{array}{l}\text { Türkçe Öğretmenleri } \\
\begin{array}{l}\text { Türk Dili ve Edebiyatı } \\
\text { Öğretmenleri }\end{array}\end{array}$ & 5 & 2 & 3 & 0 & 1 & 0 & 1 & 1 \\
\hline Toplam & 10 & 10 & 6 & 2 & 1 & 1 & 1 & 1 \\
\hline
\end{tabular}

Sınıf öğretmenlerinin öykü, masal ve fabl türleri üzerinde yoğunlaştıkları görülmüştür:

Dünya ve Türk edebiyatında değeri herkesçe anlaşılmış eserler mutlaka okutulmalıdır. Masal, öykü, fabl başta (SÖ4, 04.05.2021).

Kitabın içeriğindeki konular, olaylar anlaşılır, hayal gücü yüksek, kendisiyle ve toplumla barışık, kendini rahatlıkla ifade edebilen bireyler yetiştirmeyi ön planda tutmalıdır. Yaratıcı, yorumlamaya açık olmalıdır. Görselliği zengin olması, konuların anlaşılmasını daha da kolaylaştııı. Fabllar olabilir. Masallar ve öyküler olabilir (SÖ5, 03.05.2021).

Macera kitapları olabilir. Şiir kitapları olabilir (SÖ1, 03.05.2021).

Türkçe öğretmenlerinin ise kurgusal metinlerden gerçekçi metinlere doğru bir geçiş önerdikleri görülmektedir. Roman ve öykü türü öne çıkarken romanda bilim kurgu tarzının ortaokul düzeyinde hayal gücünü geliştireceği, kitap okumayı sevdireceği düşünülmektedir: 
Aslında beşlerden başlayarak sınıf seviyesine göre sıralamak istesem masalla başlatıp hikâye, roman, deneme diye devam ederdim. Zihinsel gelişime göre. Hayalden gerçeğe gibi (TÖ1, 26.04.2021).

Masal, bilim kurgu gibi hayal gücünü geliştirmeye yönelik kitaplar okumalı çocuk ortaokulda bence. Böylece hem hayal kurmayı öğrenir hem de severek okumay1. Fantastik roman da yine bu türlerden biri olabilir (TÖ2, 26.04.2021).

Bilim kurgu, öğrencinin önünü açmak için. Roman, masal... Kişisel ilgisine göre aslında. Bir kitabı ben çok beğenirim iki günde bitiririm ama siz beğenmezsiniz, sıradan bulursunuz. Bu ne demek? Böyle bir şey kitap okumak. Öznel bir şey (TÖ3, 26.04.2021).

Türk dili ve edebiyatı öğretmenlerinin görüşleri incelendiğinde Türk ve dünya klasikleri üzerinde yoğunlaşıldığı görülmektedir. Türk ve dünya klasikleri genellikle roman ve öykü türlerinde toplanmaktadır. Buna dayanarak Türk dili ve edebiyatı roman ve öykü türünü önerdikleri anlaşılmaktadır.

Okumayı sevdiren kitaplar... Türk ve dünya klasikleri... Kişisel gelişim kitapları olabilir... Kolay okunuyor çünkü onlar (TDEÖ1, 01.06.2021).

Klasikler demiştim aslında. İyi bir okuyucu olmak ve okuma zevki kazandırabilmek için hangi yaş grubu olursa olsun o yaş grubuna ait klasikleşen kitapları okuyarak okutarak işe başlanmalı (TDEÖ3, 01.06.2021).

Lise düzeyinde en azından çok sıkıcı olmayan klasikler, yerli ve yabancı, okusunlar. Yani tabii öğrencinin seviyesine göre değişir (TDEÖ4, 01.06.2021).

Dokuzuncu sınıflar düzeyinde dünyadaki edebi akımları yansıtan kitaplar var. Akımları tanıması açısından, yani başat özelliklerini anlaması açısından belli başlı eserleri okursa o akımlar hakkında bilgi sahibi olabilir diye düşünüyorum (TDEÖ5, 07.01.2021).

Tüm branşlar birlikte değerlendirildiğinde özellikle öykü ve roman türünün öne çıktığ1 ifade edilebilir.

\section{Sonuç}

İlkokul, ortaokul ve ortaöğretim kademelerinde görev yapmakta olan sınıf, Türkçe ve Türk dili ve edebiyatı öğretmenlerinin öğrencilere kitap önerirken göz önünde bulundurdukları ölçütleri ortaya koymak ve çocuk edebiyatı eserlerinde bulunması gereken temel ölçütler bağlamında değerlendirmek amacıyla gerçekleştirilen bu araştırmada yarı yapılandırılmış görüşme formundaki sorulara öğretmenlerin verdikleri cevapların analiz edilmesiyle ulaşılan bulgular ve bu bulgulara ilişkin yorumlardan yola çıkılarak öğretmenlerin çocuk edebiyatı ürünlerinde en çok çocuğa görelik ilkesine önem verdikleri sonucuna ulaşılmıştır. Çocuğa görelik ilkesine uygun edebi eserler dendiğinde çocuğun fiziksel ve psikolojik gelişimine, çocuğun kelime dağarcığına ve çocuğun dünyayı algılama şekline uygun şekilde kaleme alınmış eserler anlaşılmalıdır (Şirin, 2000). Çocuk edebiyatı ürünleri de mutlaka çocuğa görelik ilkesi gözetilerek hazırlanmalıdır (Varışoğlu ve Tuzcuoğlu Aksin, 2019).

... çünkü çocukların doğru, açık, etkili ve estetik bir biçemle iletişim ve etkileşim içinde olmaları, anlama ve anlatma becerilerini yetkinleştirmeleri, üst düzey düşünme 
becerileri kazanmaları, sanatçı duyarlığını sezinlemeleri, anadili sevgisi ve bilincini duyumsamaları, Türkçenin yaratıcı anlatım olanaklarının farkında olmaları, sözcük dağarcıklarını geliştirmeleri, kişilik ve toplumsal gelişimlerine katkıda bulunmaları, okuma sevgisi ve alışkanlığ kazanmaları, kavramsal gelişimlerini desteklemeleri, düş dünyalarını zenginleştirmeleri, keşfetme ve serüven içinde olmaları, onların gelişim düzeylerine uygun, sanatçı duyarlığıyla hazırlanmış yazınsal nitelikli yapıtların ... gerektiğini ortaya çıkartır (Çer, 2016c, s. 1406).

$\mathrm{Bu}$ araştırmada, öğrencilerin yaş ve gelişim seviyelerine bağlı olarak öğretmenlerin kitapların içerik yönüyle ilgili beklentilerinin yerini dil ve anlatım unsurlarının aldığı sonucuna ulaşılmıştır. Kuşdemir ve Bulut'un (2019) da ifade ettiği gibi “Çocuklar için yazılan hikâyelerde konunun açık ve anlaşılabilir olması, insana özgü duyguların çocuğun anlayabileceği biçimde ifade edilmesi, çocuğu sosyal hayata hazırlaması; dil anlatım yönünden Türkçe'nin anlatım inceliğini göstermesi gerekmektedir" (s. 148). Ancak bu çalışmada öğretmenler, çocuk edebiyatı ürünlerinde en çok karşılaştıkları olumsuzlukların argo, küfür ve yaşa uygun olmayan dil kullanımı olduğunu ifade etmişlerdir. Çocuk edebiyatı ürünleri çocuğun dil ve düşünce evrenine uygun bir dil ve anlatımla, iletisini örtük biçimde vermeli, çocuğun sezgi ve duyumsama gücünü kullanıp geliştirmesine imkân sağlamalıdır (Çer, 2016c).

Efe'ye göre (2014, s. 475) çocuk edebiyatı, ideolojik bağnazlığa kurban edilemeyecek kadar önemli bir kavramdır. Çocuklara katı toplum ve ahlâk kuralları aşılamaya çalışan, öğüt verici nitelikte edebi yapıtlar şüphesiz çocuğun ilgisini çekmeyecek; ideolojik bir içerik ve anlatıma sahip olan yapıtlar ise çocuklara eleştirel ve tarafsız düşünme becerisi kazandırma işlevini yitirecektir (Tekin ve Büyükikiz, 2018, s.115). Yetişkinlerin kendi doğrularını ya da ideolojilerini kitaplar aracıllğıyla çocuklara empoze etmeye çalışmaları çocukları kendi gerçeklerinden uzaklaştırabilir. Bu gibi sorunların ortadan kaldırılması için en kısa zamanda çocuk yazını etiğinin oluşturulması ve hem yazarların hem de çizerlerin çocuğu olumsuz etkileyebilecek eserler ortaya koyma konusunda duyarlık geliştirmesi sağlanmalıdır (Sever, 2002).

Çocuk edebiyatı ürünleri; dil ve estetiğin gücünü kullanarak çocuklara eğitsel nitelikli iletiler vermek amacıyla yazılırlar ancak “...çocuk kitaplarında yer alan metinlerin bilgi iletmek ya da öğretmek yerine duyumsatıcı ve sezinletici olmasına, çocuğu metnin anlamına götürecek uygun ipuçlarına, sözcüklerin bilinen anlamlarının dışında kullanılmasına, söz değerlerine yeni anlamlar yüklenmesine, renk, çizgi ve sözcüklerin anlatım gücüne gereksinim vardır" (Çer, 2016c, s. 1401). Demirel, Geçen, Seven, Tozlu ve Uludağ'ın hazırladıkları çalışmada (2011, s. 58-59) çocuk kitaplarındaki eğitsel iletilere ilişkin nitelikleri şöyle açıklamışlardır:

İletiler çocuğun bilişsel, duyuşsal gelişim özelliklerine uygun olmalı, çocuğun söz konusu gelişim boyutlarına olumlu katkılarda bulunmalıdır. İletiler ile konu-tema arasında yakın bir ilişkinin olmasına dikkat edilmeli. İletilerin aktarımında önemli bir araç olan konu, dil ve anlatım gibi özellikler, kendi içlerinde bir uyumu barındırmalıdır. İletilerin aktarımında anlatılan metnin özelliği de dikkate alınarak, elden geldiğince zengin bir yola başvurmalıdır. Yani sadece örtük iletiler şeklinde 
değil, yerine göre doğrudan, dolaylı ve soru şeklindeki iletiler de metnin içine yedirilmiş olmalıdır. İletiler tıpkı tema/ ana fikir gibi eserin yazılma nedeni hâline gelebileceği için en az tema/ ana fikir kadar üzerinde ciddi bir biçimde durulmalıdır.

Yazıcı Okuyan (2009) öğretmenlerin öğrencilerine kitap seçerken daha çok kitapların eğitsel boyutunu dikkate alarak kitap seçtiklerini belirtmiştir. Öğretmenlerin çocuk kitaplarında aradıkları nitelikleri ortaya koymak için gerçekleştirmiş olduğumuz bu araştırmada da çocuk edebiyatı ürünlerinin eğitsel yönünün tüm branşlar tarafından en çok önemsenen özellik olduğu sonucuna ulaşılmıştır. Bu sonuç; Yazıcı Okuyan'ın (2009) ilgili araştırması ve alan yazında ifade bulan kavramsal çerçeve ile tutarlıdır.

Öğretmenlerin öğrencilerine en çok önerdikleri türler arasında roman ve öykü türlerinin yer aldığı, bu türleri masal türünün takip ettiği görülmektedir. Araştırmadaki bu sonuç; Kolaç, Emir ve Karadağ'ın (2012) Türkçe öğretmeni adaylarının dil gelişimini en çok destekleyen metin türlerinin başında öyküyü gördüklerini belirttikleri araştırmaları ile de tutarlıdır. İlgili araştırmanın bulgularına göre öykü türünü sırasıyla; masal, ninni, tekerleme, fabl gibi türler izlemektedir. Kütüphaneleri kullanan öğrencilerin ağırlıklı olarak hikâye ve roman türündeki kitapları ödünç aldıkları sonucuna ulaşan araştırmalar da bu çalışmanın sonucunu destekler niteliktedir (Acıyan, 2008; Taşkesenlioğlu, 2013). Öğretmen görüşleri ayrıntılı olarak incelendiğinde sınıf öğretmenleri arasında bir eser adı üzerinde yoğunlaşılmadığı, daha çok öykü ve fabl türlerinde her yıl değişen önerilerde bulundukları görülmüştür. Türkçe öğretmenlerinin Nutuk ve Beyaz Zambaklar Ülkesinde adlı kitaplar üzerinde yoğunlaştıkları; Türk dili ve edebiyatı öğretmenlerinin ise bir eser ismi vermektense genel olarak Türk ve dünya klasiklerinden sembol eserlerin okutulması gerektiği kanaatinde birleştikleri görülmüştür.

\section{Kaynakça}

Acıyan, A. A. (2008). Ortaöğretim öğrencilerinin okuma alışkanlıkları ve akademik başarı düzeyi arasındaki ilişsi [Yayımlanmamış yüksek lisans tezi]. Yeditepe Üniversitesi Sosyal Bilimler Enstitüsü Eğitim Yönetimi ve Denetimi Ana Bilim Dalı.

Akyüz, M. Y. (2014). Muzaffer İzgü'nün çocuk kitaplarının çocuk edebiyatının temel ilkeleri açısından incelenmesi [Yayımlanmamış doktora tezi]. Ankara Üniversitesi Eğitim Bilimleri Enstitüsü Eğitimin Kültürel Temelleri Anabilim Dalı Türkçe Eğitimi Bilim Dalı.

Arıkan, Y., ve İnce Samur, A. Ö. (2020). Behiç Ak'ın çocuk kitaplarının çocuk edebiyatının temel öğeleri bakımından incelenmesi. Çocuk Edebiyat ve Dil Eğitimi Dergisi, 3(2), 181-202.

Ateş, S., Çetinkaya, Ç., \& Yıldırım, K. (2012). Öğretmen, ebeveyn ve öğrencilerin görüşlerine göre ilköğretim öğrencilerinin okuma çevreleri. International Online Journal of Educational Sciences, 4(2), 377-394.

Batur, Z., ve Alevli, O. (2014). Okuma becerileri dersinin PISA okuduğunu anlama yeterlilikleri açısından incelenmesi. Okuma Yazma Eğitimi Araştırmaları, 2(1), 22-30.

Çer, E. (2016a). Çocuk Edebiyatı: 0-6 Yaş Çocuk Kitaplarında Çocuk Gerçekliği ve Çocuğa Görelik. Eğiten Kitap.

Çer, E. (2016b). Preparing for books children from birth to six: The approach of appropriateness for the child. Journal of Education and Practice, 7(6), 78-99.

Çer, E. (2016c). Türkçe öğretiminde çocuğa görelik ilkesine uygun edebiyat yapıtlarının önemi. Ilkögretim Online, 15(4), 1399-1410. 
Öğretmenlerin Kitap Önerisinde Kullandıkları Ölçütlerin Çocuk Edebiyatının Temel İlkelerine Göre İncelenmesi

Çolaklar, H. (2019). Bartın il halk kütüphanesindeki okul öncesi dönem çocuk kitaplarının dış yapı ölçütleri: Yazım, dil, biçim ve içerik özelliklerine göre değerlendirilmesi. Bilgi Yönetimi Dergisi, 2(2), 145-168.

Demircan, C. (2006). TÜBİTAK çocuk kitaplığı dizisindeki kitapların dış yapısal ve iç yapısal olarak incelenmesi. Mersin Üniversitesi Eğitim Fakültesi Dergisi, 2(1), 12-27.

Demirel, Ş., Geçen, M. A., Seven S., Tozlu, N ve Uludağ, M. A. (2011). Edebî metinlerle çocuk edebiyatı. Pegem Yayınc1lik

Dilidüzgün, S. (2000). Çocuk kitaplarında yazınsal nitelikler. I. Ulusal Çocuk Kitapları Sempozyumu Bildiriler Kitabı. Ankara Üniversitesi Basımevi.

Efe, A. (2014). Çocuk edebiyatında ideoloji üzerine bazı düşünceler. Türk Dili, 107(756), 472-475.

Gedikoğlu Özilhan, Y. G. (2016). Çocuk romanlarının demokratik kültür bilinci edinimine etkisi (Burdur ili örneği). Dil Eğitimi ve Araştırmaları Dergisi, 2(3), 51-70.

Gürcan, H. İ. (1999). Okuma alışkanlı̆̆ ile kitap yayımcılı̆̆ının kültürel iletişim ve teknolojisine bağlı sorunları karşısında Türkiye koşulları temelinde bir model önerisi. Anadolu Üniversitesi Yayınları.

Karatay, H. (2011a). Karakter eğitiminde edebi eserlerin kullanımı. Electronic Turkish Studies, 6(1), $1439-1454$.

Karatay H. (2011b). Çocuk edebiyatı metinlerinde bulunması gereken özellikler. T. Şimşek (Ed.), Kuramdan uygulamaya çocuk edebiyatı el kitabı (ss.77-123). Grafiker Yayınları.

Kaya, M. (2007). Okuma yazma öğretiminde çocuk edebiyatının öğretim amaçlı kullanımındaki yöntem ve teknikler. II. Ulusal Çocuk ve Gençlik Edebiyatı Sempozyumu (Gelişmeler, Sorunlar ve Çözüm Önerileri) (ss. 117-122). Ankara Üniversitesi Basımevi.

Kolaç, E., Demir, T. ve Karadağ, R. (2012). Öğretmen adaylarının dil eğitiminde çocuk edebiyatı metinlerinin kullanımına yönelik görüşleri. Türkiye Sosyal Araştırmalar Dergisi, 161(161), 118.

Lifshitz, J. (2016). Curating empathy. Literacy Today, 33(6), 24-26.

Maltepe, S. (2009). Türkçe öğretmeni adaylarının çocuk edebiyatı ürünlerini seçebilme yeterlilikleri. Balıkesir Üniversitesi Sosyal Bilimler Enstitüsü Dergisi, 12(21), 398-412.

Merriam, S. B. (2009). Qualitative research: A guide to design and implementation. John Wiley-Sons.

Oral, F. (1994). Okulöncesi çocuk kitabında nitelik anlayışı ne olmalıdır? M. R. Şirin (Ed.), 99 Soruda Çocuk Edebiyatı (ss. 150-152). Çocuk Vakfı Yayınları.

Özbay, M. (2009). Anlama teknikleri 1: Okuma eğitimi. Öncü Kitap.

Sever, S. (1995). Çocuk kitaplarında bulunması gereken yapısal ve eğitsel özellikler. Abece Dergisi (107), 14-15.

Sever, S. (2000, Ocak). Çocuk kitaplarında dilsel ve görsel duyarlık. I. Ulusal Çocuk Kitapları Sетровуити (ss. 20-21).

Sever, S. (2002). Çocuk kitaplarına yansıtılan şiddet (Milli Eğitim temel yasası ve çocuk haklarına dair sözleşme bağlamında bir değerlendirme). Ankara Üniversitesi Eğitim Bilimleri Fakültesi Dergisi, 35(1-2), 25-37.

Sever, S. (2006, 4-6 Ekim). Çocukla yazınsal iletişim. II. Çocuk ve Illkgençlik Edebiyatı Sempozyumu Kurultayl (ss. 39-65).

Sever, S. (2008). Çocuk ve edebiyat. Tudem Yayınları.

Sever, S. (2013). Çocuk edebiyatı ve okuma kültürü. Tudem Yayınları. 
Şirin, M. R. (2000). 99 soruda çocuk edebiyatt. Çocuk Vakfı Yayınları.

Şirin, M. R. (2007), Çocuk edebiyatına eleştirel bir bakış- Çocuk edebiyatı nedir ne değildir? Kök Yayıncilik.

Şirin, M. R. (2016). Edebiyat ve çocuk edebiyatı: Edebiyatın amacı ve işlevi. Türk Dili Dergisi, CX(780), 12-31.

Taşkesenlioğlu, L. (2013). Ortaöğretim öğrencilerinin okuma alışkanlıkları üzerine bir inceleme. Karadeniz Sosyal Bilimler Dergisi, 5(9), 261-273.

Tekin, A., ve Büyükikiz, K. K. (2018). Aytül Akal'ın çocuk kitaplarının eğitsel iletiler açısından incelenmesi. Okuma Yazma Eğitimi Araştırmaları, 7(2), 110-123

Türkben, T. ve Avan, H. G. (2020). Michael Ende'nin "Momo" adlı eserin çocuk edebiyatının temel ilkeleri açısından incelenmesi. Türkiye Sosyal Araştırmalar Dergisi, 24(2), 451-467

Varışoğlu, B. ve Tuzcuoğlu Aksin, Ş. H. (2019). Andrew Clements'in Bunun adı Findel adlı çocuk edebiyatı eserinin çocuğa görelik açısından incelenmesi. RumeliDE Dil ve Edebiyat Araştırmaları Dergisi, (16), 639-656. DOI: 10.29000/rumelide.619651.

Yazıcı Okuyan, H. (2009). Türkçe ve sınıf öğretmenlerinin okuma saatlerinde kullanılan çocuk edebiyatı ürünlerini seçme ölçütleri. Mehmet Akif Ersoy Üniversitesi Eğitim Fakültesi Dergisi, (18), 135-159.

Yıldırım, A. ve Şimşek, H. (2018). Sosyal bilimlerde nitel araştırma yöntemleri. Seçkin Yay. 